\title{
Origin and Geochemical Processes of Porewater in Clay-Rich Deposits in the North Jiangsu Coastal Plain, China
}

\author{
Qin Ge, ${ }^{1}$ Xing Liang, ${ }^{1,2}$ Menggui Jin, ${ }^{1,3}$ Jing Li, ${ }^{1}$ and Yan Liu ${ }^{4}$ \\ ${ }^{1}$ School of Environmental Studies, China University of Geosciences, Wuhan 430074, China \\ ${ }^{2}$ Hubei Province Key Laboratory of Wetland Evolution and Ecology Restoration, \\ China University of Geosciences, Wuhan 430074, China \\ ${ }^{3}$ State Key Laboratory of Biogeology and Environmental Geology, China University of Geosciences, Wuhan 430074, China \\ ${ }^{4}$ Key Laboratory of Ministry of Land and Ground Fissure Disaster, Nanjing 210018, China \\ Correspondence should be addressed to Xing Liang; xliang@cug.edu.cn
}

Received 2 June 2017; Revised 19 September 2017; Accepted 1 November 2017; Published 13 December 2017

Academic Editor: James Hendry

Copyright (c) 2017 Qin Ge et al. This is an open access article distributed under the Creative Commons Attribution License, which permits unrestricted use, distribution, and reproduction in any medium, provided the original work is properly cited.

\begin{abstract}
The hydrogeochemical and stable isotope compositions of aquitard porewater samples from three boreholes were investigated to determine the origin, salinization, and hydrochemical evolution of water in the North Jiangsu coastal plain, China. Three porewater groups were identified based on the water-bearing subsystems. The total dissolved solids (TDS) of porewater samples highly varied from 0.03 to $26.1 \mathrm{~g} / \mathrm{L}$. Molar $\mathrm{Cl} / \mathrm{Br}$ ratios and $\delta^{18} \mathrm{O}$ and $\delta^{2} \mathrm{H}$ data indicate that the source of Group 1 salinized porewater was the Holocene seawater, whereas Group 3 salinized samples were probably related to the remnant palaeoseawater of the Late Pleistocene. Group 2 samples had low salinity (TDS $<1 \mathrm{~g} / \mathrm{L}$ ) and undetectable $\mathrm{Br}^{-}$concentrations, which were probably recharged during a colder period and without evidence of seawater involvement. The salinized porewater was likely diluted by freshwater, as evidenced by its depleted isotopes and low salinity relative to standard seawater. The ionic ratios and ionic deltas indicate that considerable waterrock interactions (e.g., cation exchange and mineral weathering) also accounted for the hydrochemical constituents of porewaters, and cation exchange seems to be more noticeable at low salinity.
\end{abstract}

\section{Introduction}

Coastal areas are among the most densely populated areas in the world; it is estimated that half of the world's population lives in coastal areas [1]. In China, the continental coastline exceeds $18,000 \mathrm{~km}$, and more than $60 \%$ of the population lives in 14 coastal provinces [2]. With rising population levels and growing industrial development, vulnerable water resources seem to be overused, especially in these coastal areas $[3,4]$.

Water management problems can be exacerbated by the presence of saline groundwater. Groundwater salinization is likely associated with modern seawater intrusion due to overpumping [5, 6], contributions of deep saline waters (fossil seawater) [7-9], and water-rock interaction with evaporates $[10,11]$. Research suggests that released porewater from the adjacent aquitards is a substantial proportion of the amount of aquifer groundwater that can be exploited [12]. Aquitards act as natural protective barriers for underlying aquifers and also contain large amounts of salt and contaminants that may leak into aquifers $[13,14]$. In the context of potential recharge sources for aquifers, the successful description of porewater constituents and hydrochemical processes involved in coastal aquitards will benefit the sustainable exploitation, evaluation, and protection of groundwater resources in aquifers.

Hydrochemical and stable isotopes of groundwater in aquifers have classically been considered tools to deduce the sources of dissolved salts $[8,15,16]$. By contrast, few studies have examined porewater in aquitards even though aquitards commonly have a greater capability to contain water with high salinity relative to aquifers $[17,18]$. Diffusion is considered the dominant mechanism of the transport of solutes in the coastal aquitards [19]. Porewater salinity in aquitards cannot simply relate to seawater intrusion and may involve complex geochemical processes (such as water-rock interaction) because of the extremely long residence time of water in aquitards [20, 21]. Further, a combination of past and recent 
processes, possibly including several phases of regression, transgression, formation of salt water, and mixing, can result in salinization of porewater [8]. In China, the sources of saline porewater in the coastal plain aquitards are still not clear.

In North Jiangsu coastal plain, the hydrogeological conditions have been studied comprehensively [4, 22, 23]. Most of the saline and brackish groundwater samples in the aquifers were found to be derived from relict seawater [4], because three marine invasions and regressions have occurred along the coastal area of eastern China since the Late Pleistocene [24]. As a result of the interest in the hydrochemical processes of porewaters in the clay-rich deposits, major ions and stable isotopes $\left(\delta^{18} \mathrm{O}, \delta^{2} \mathrm{H}\right)$ are used in the present study to provide insight into the salinity sources, mixing behaviors, and hydrochemical evolution. The objectives of this paper are (1) to analyze the vertical distribution of hydrochemistry and stable isotopic signatures of porewater in three cores (SY1, SY2, and SY3) in North Jiangsu coastal plain, (2) to ascertain the primary salinity sources of porewater and the mixing between seawater and freshwater, and (3) to determine waterrock reaction processes by using geochemical indicators.

\section{Study Area}

2.1. Hydrogeological Setting. This study examined three cores located in North Jiangsu coastal plain, China, adjacent to the south Yellow Sea (SY1: $33.82^{\circ} \mathrm{N}, 120.43^{\circ} \mathrm{E}$; SY2: $33.80^{\circ} \mathrm{N}$, $120.32^{\circ} \mathrm{E}$; SY3: $34.40^{\circ} \mathrm{N}, 119.81^{\circ} \mathrm{E}$ ) (Figure $1(\mathrm{~b})$ ). The North Jiangsu coastal plain has a continental and maritime climate, with a mean annual temperature of $13-16^{\circ} \mathrm{C}$. The average annual precipitation is approximately $800-1,200 \mathrm{~mm}$, and nearly $30-60 \%$ of the annual precipitation falls from June to September. The annual evaporation is $900-1,050 \mathrm{~mm}$.

That transgressions and regressions occurring frequently in the Quaternary period have been confirmed in published studies $[25,26]$. The depositional facies of aquitards change from alluvial and lacustrine to marine sediments from west to east on the coastal plain, mainly because of the development of the Huai River and Yellow River, climate change, and transgressions and regressions [27, 28]. The major aquitards are widely dispersed in this study area and generally consist of Quaternary sediments with thickness of $15-75 \mathrm{~m}$ in the east and up to $100 \mathrm{~m}$ in the west [28]. Four porewater types, namely, salt-fresh water inversion, salt-brackish water inversion, salt-fresh-brackish water superimposition, and salt-freshsalt-fresh superimposition, were confirmed on the basis of the ions and the TDS analysis of porewater from the southern borehole sediments of this region [29]. Data from the northeastern regions were not readily available.

Quaternary aquifers are observable from the single aquifer to multiaquifer system from the west to the east [30]. Three partially connected confined aquifers exist in Quaternary sediments of this study area (Figure 2). These aquifers are composed of sandy gravel, medium-fine sand, and fine sand and are separated by silt- and clay-dominated aquitards. Aquifer groundwater flow in the confined aquifers is generally from west to east under natural conditions with relatively low velocity and with a hydraulic gradient of approximately $2 / 10,000$ [4]. Geochemical analysis indicates that phreatic aquifer can be divided into two zones: the fresher zone (a thin layer about $2.0-2.5 \mathrm{~m}$ thick below the water table) and the saline zone. Phreatic aquifer is trapped in marineterrigenous deposits that correspond to the Holocene $\left(Q_{4}\right)$ formation. Phreatic aquifer in the fresher zone generally has TDS concentrations within 1-2 g/L and tends to be less saline than the water in the underlying saline zone as a result of the diluted influence of atmospheric precipitation. Phreatic aquifer in the saline zone and shallow confined aquifers are saline with TDS mostly over $3 \mathrm{~g} / \mathrm{L}$. The TDS concentrations of saline water exhibit an increasing trend from the west to east. The saline aquifer groundwater mainly originated from seawater and then was mixed with the recharge of precipitation and irrigation water [4]. Groundwater in the second confined aquifer exhibits the chemical signature of freshwater and was trapped in the fluvial deposits during the Middle Pleistocene $\left(Q_{2}\right)$ [30]. The third confined aquifer groundwater has relatively high TDS $(>1 \mathrm{~g} / \mathrm{L})$, which could be related to residual seawater [22]. Additionally, leakage recharge from the upper shallow aquifer groundwater may play a key role in contributing to the source of deep confined groundwater during groundwater exploitation.

2.2. Local Stratigraphy. Three cores were drilled on-site between 2013 and 2015, to depths of $250 \mathrm{~m}, 120 \mathrm{~m}$, and $350 \mathrm{~m}$, respectively. The stratigraphy of the study boreholes was composed of Neogene and Quaternary deposits (Figure 3). Clay, silty clay, silt, and sand were noted in the field drilling logs that described the observed core sediments. The dominant sediments generally consisted of fine-grained deposits derived from an alluvial fan.

The upper 2-3 $\mathrm{m}$ of the deposit was visibly fractured and weathered, and below that layer, the deposits were grey with no visible fractures. Various lithological facts and the aquifers distribution can be observed from Figures 2 and 3. The approximate chronostratigraphic framework of three cores in the column was provided on the basis of Kang [30] and Zheng [31]. The Early Pleistocene sediments were primarily composed of clay, medium-coarse sand, and silt-fine sand interlayers. The Middle and Late Pleistocene layer mainly consisted of clay with silt-fine sand interlayers. The Holocene layer is dominated by clay and silty clay.

The mineralogy of the clay-size fraction of the aquitards from the middle reaches of Huai River and southern Yellow Sea is composed of $52 \%-82 \%$ illite, $6 \%-16 \%$ chlorite, $5 \%-14 \%$ kaolinite, and $1 \%-15 \%$ smectite $[32,33]$, with only minor amounts of quartz [34]. Illite (17-76\%) and chlorite (6\%-17\%) are the major components of these core samples; a certain amount of quartz, albite, and calcite is also found in the deposits.

\section{Methods}

Field work was conducted on-site using a rotary drill. Between January and February 2013, continuous core samples were collected at borehole SY1. To improve the sample density for the reliability of hydrochemical data and obtain other high-salinity porewater samples in deep clay-rich sediments, additional continuous core samples were collected at the SY2 

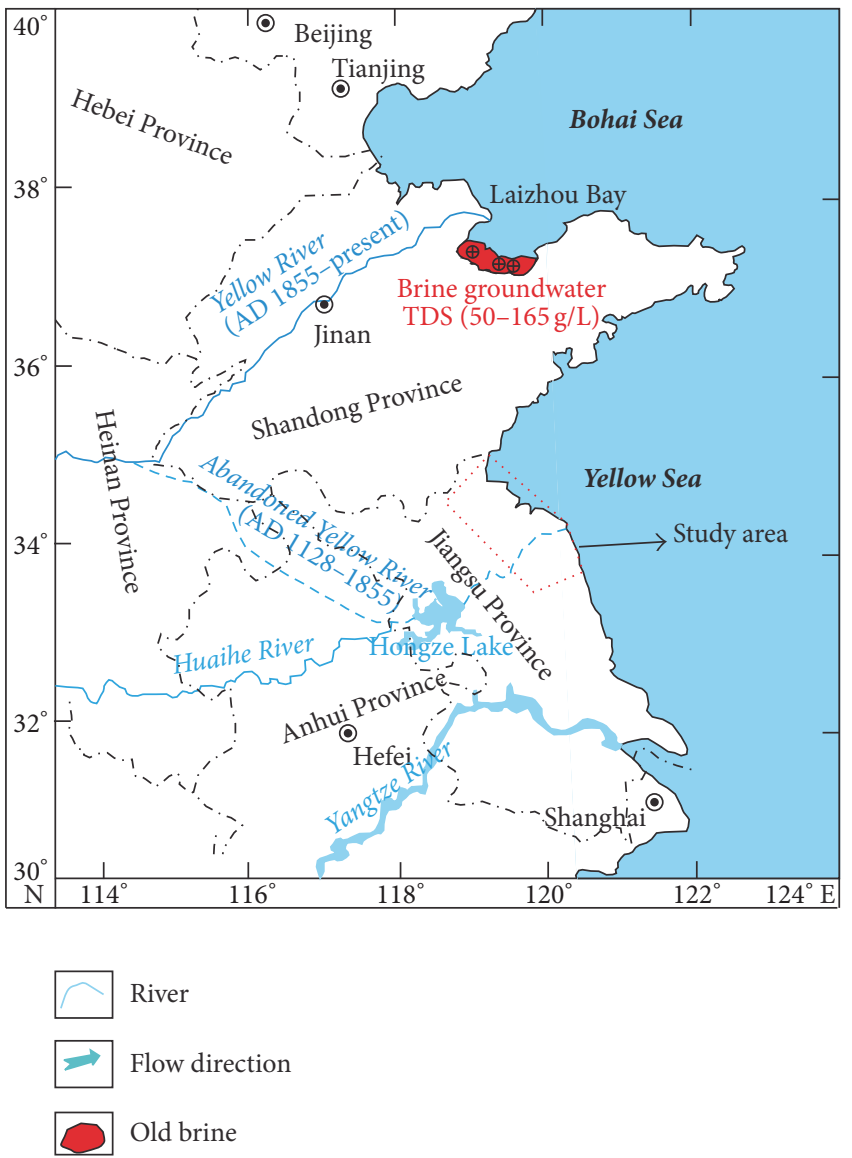

(a)

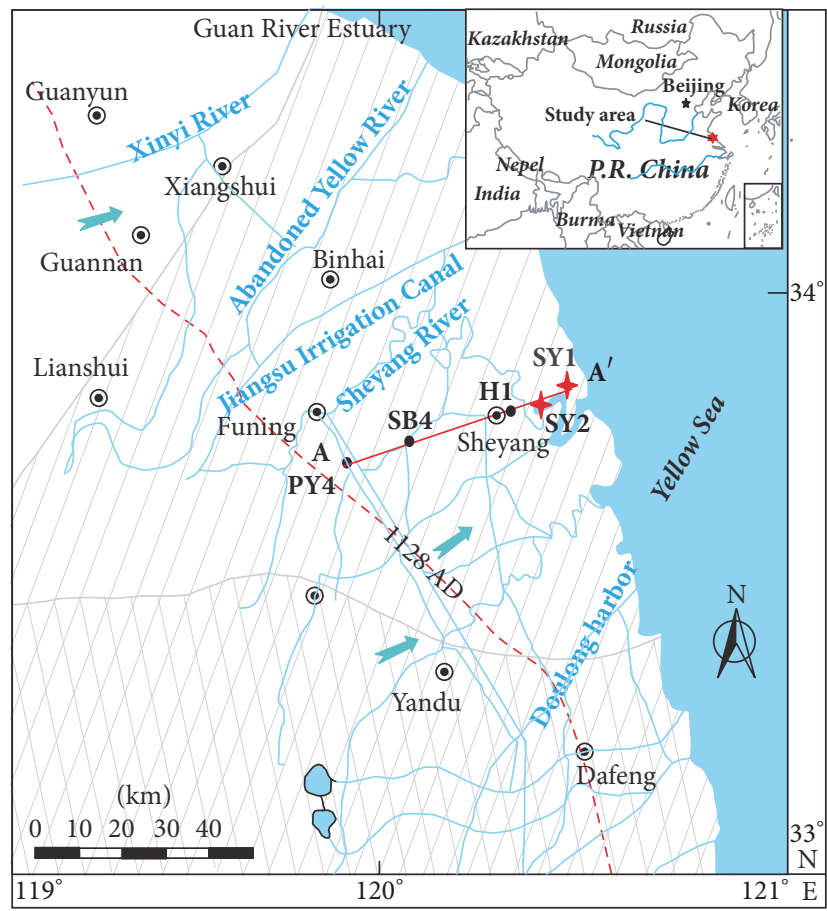

$\checkmark$ Zoning boundaries

1128 AD coastal line

$\square$ Lower reaches of the Huaihe River

Cross region of lower reaches of the Huaihe River and the Yangtze River

(b)

FIGURE 1: Location map of the research area. The A- $\mathrm{A}^{\prime}$ line indicates the location of the cross-section displayed in Figure 2.

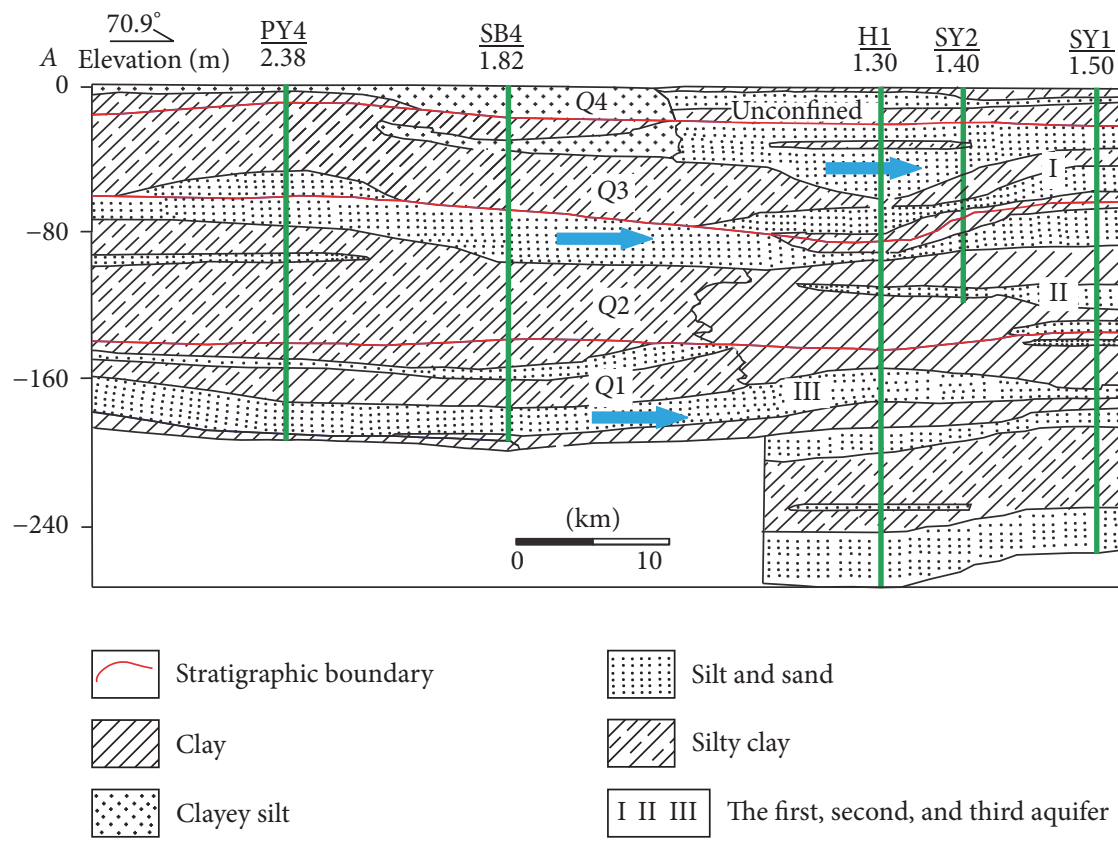

FIgURE 2: A-A' cross-section of the study area. SY1 and SY2 cores are displayed in the cross-section. 


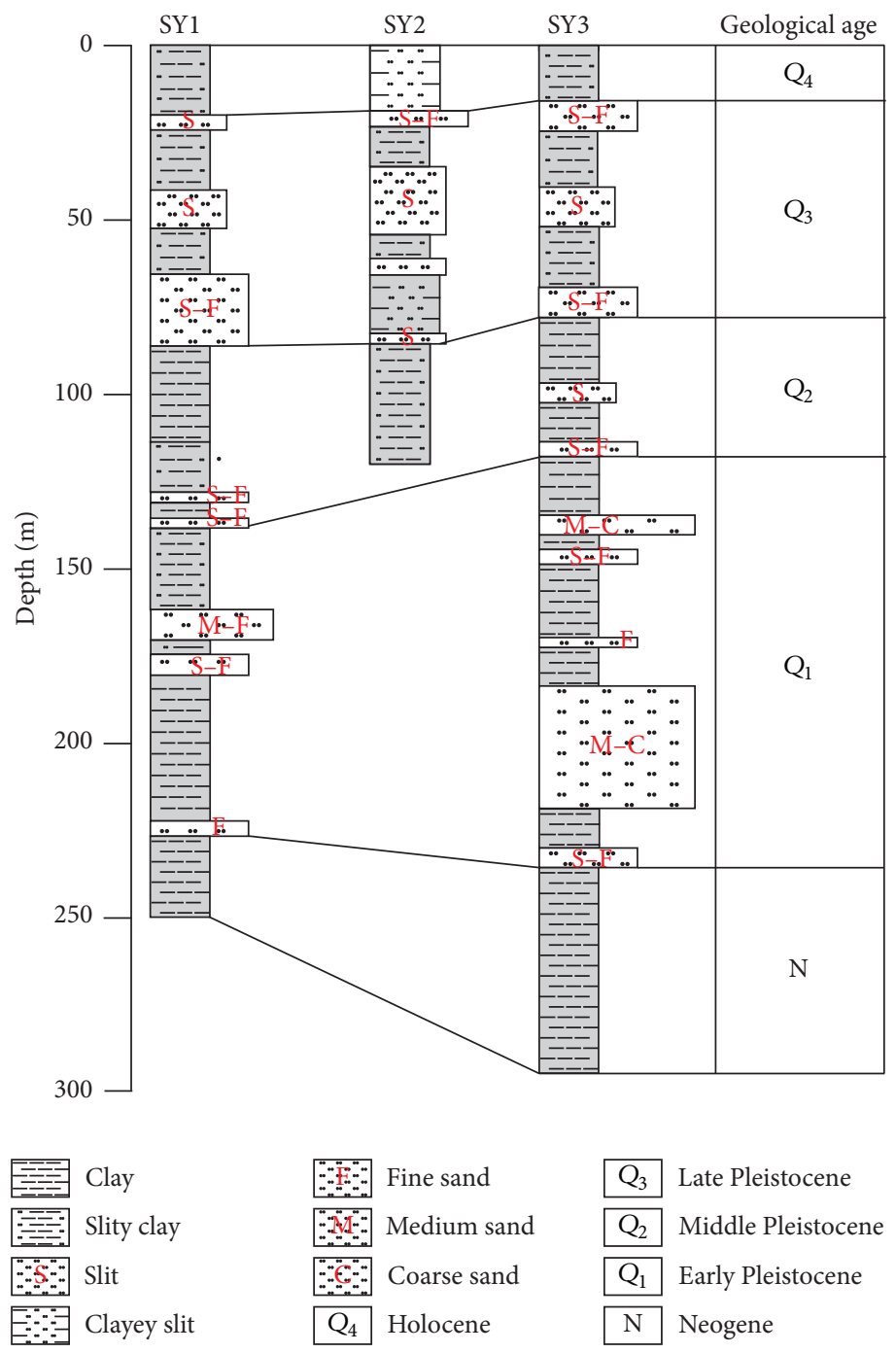

Figure 3: Stratigraphic columns of the drilled three boreholes in North Jiangsu coastal plain. The observed deposit distributions across the cores are illustrated.

and SY3 cores in December 2014. The distances between borehole SY1 and borehole SY2, borehole SY1 and borehole SY3, and borehole SY2 and borehole SY3 were $10 \mathrm{~km}, 86 \mathrm{~km}$, and $81 \mathrm{~km}$, respectively.

Forty-four core samples (length: $20 \mathrm{~cm}$; diameter: $8 \mathrm{~cm}$ ) were collected in SY1 core, 26 samples in SY2, and 15 samples in SY3 core to extract porewater for chemical analysis. The collected samples were packaged in a sealable aluminum barrel and sealed with wax. Immediately after retrieval and before packing, the outer $2-3 \mathrm{~cm}$ of the samples was removed and discarded, excluding the contamination of the drilling fluid. The collected core samples were squeezed using high pressure to obtain porewater samples for chemical analyses.

From the boreholes SY2 and SY3, 25 and 11 core samples were collected on-site by $10 \mathrm{~mL}$ glass bottles to extract porewater for stable isotopic analyses. Subsequently, the selected samples were sealed using raw adhesive tape to avoid moisture loss. All samples were stored in insulated coolers at approximately $4^{\circ} \mathrm{C}$ prior to analysis to minimize the growth of microorganisms.
3.1. Porewater Extraction Method. Initially, researchers mostly focused on high-porosity clays, because porewater could be easily extracted from those clays by installing piezometers in shallow aquitards (at depths not greater than $100 \mathrm{~m}$ ) in situ $[35,36]$. Recently, for research into the deep, low-permeability clays, concentrations of porewater were mostly based on the ion concentrations of leach solutions from core deposits. Then, ion concentrations of the leach solutions were converted to in situ porewater concentrations [37, 38]. However, many parameters (e.g., dry bulk density and effective porosity) are required in this method and the parameters retained some errors during the test. In this study, the thicker cohesive soil was focused on. To avoid any transforming error, an ex situ mechanical squeezing method was used in this study to collect porewater [21, 39]. Various studies have described such mechanical squeezing methods in detail $[40,41]$.

The design of the squeezing device was based on the squeezing method of Patterson et al. [41] and $\mathrm{N}_{2}$ pressurizing equipment was added and applied to a piston to produce 


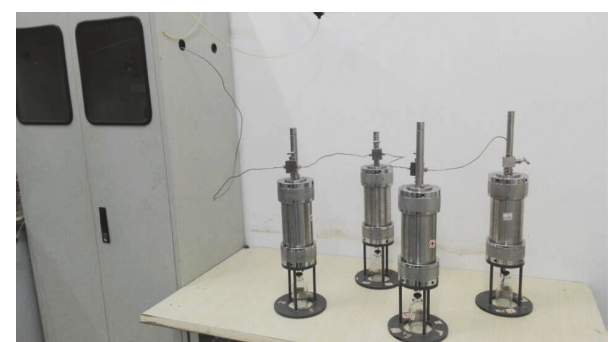

Figure 4: The photograph of the squeezing device.

pressures of up to $8 \mathrm{MPa}$ (Figure 4). The squeezing device consisted of an Inox chamber, two porous plates, a top cover, a bottom cover, several screws, and a $\mathrm{N}_{2}$ gas holder. To prevent any effect from air exposure and ionic reactions on porewater composition, a stainless steel cylinder contained the sediments. The connections between the top and bottom endplates and the Inox chamber were sealed with O-rings. Böttcher et al. [42] suggested that porewater chemistry could be modified when pressures were as high as $60 \mathrm{MPa}$ due to the collapse of soil structures. Thus, this method is considered suitable for fine-grained and organic-matter-sediments [41].

The outermost $1-2 \mathrm{~cm}$ of the prepared core samples was scraped to discard any materials that could have been altered by exposure to the atmosphere (oxidation). Each sample (approximately $1000 \mathrm{~g}$ ) was trimmed into separate pieces to fit the sample chamber. About 10-20 min was required until the core samples were inserted into the sample chamber. Some tens of millilitres of air might exist in the space of sample chamber; any air present in the chamber would be expelled during the first half hour of each sample squeezing test. Furthermore, the water collection bottle was assembled to the outlet hole after this phase to eliminate air in the bottle. To avoid overconsolidation or destruction of the clay-pore system, the applied stress was increased to $8 \mathrm{MPa}$ gradually rather than in a single step. First, a small stress of approximately $1 \mathrm{MPa}$ was initially applied to expel most of the air in the sample chamber and to ensure that the sample was bedded. Second, the applied stress was increased by $1 \mathrm{MPa}$ every 4-5 hours during the day. Finally, after about 72-96 h, approximately 8-70 $\mathrm{mL}$ of porewater was collected in the clean bottle from the center hole of the bottom endplate. The water samples were weighed and filtered through a $0.45 \mu \mathrm{m}$ membrane and immediately stored in a refrigerator at $4^{\circ} \mathrm{C}$ before being analyzed.

Because of the high salinity $(>1 \mathrm{~g} / \mathrm{L})$ of many porewater samples, vacuum distillation was selected to collect porewater for stable isotope analysis. The vacuum distillation technique is widely used to extract porewater from core samples. If the extraction had not been complete, it might have produced a systematic depletion in heavy isotopes due to the influence of isotope fractionation [43]. The extraction temperature, sample grain size, and the extraction time were the major factors that influenced the porewater extraction $[44,45]$. In addition, it is suggested that the depletion tended to increase as the water content of the deposits decreased, especially for clay samples $[44,46]$. The fractionation effects can be negligible when the sediment samples have water content proportions that exceed $0.15[45,47]$. In this study, each of the samples (about $15 \mathrm{~g}$ ) with high water content $(0.21-0.27$ by weight) was placed in an airtight glass tube and connected to the modified extraction line. All extraction apparatuses were made of glass. Porewater was extracted through vaporization at approximately $120^{\circ} \mathrm{C}$ and heated for $6-7 \mathrm{~h}$ in vacuum. The extraction time was verified to ensure complete extraction.

3.2. Water Sample Analysis. All extracted porewater samples were filtered through a $0.45 \mu \mathrm{m}$ membrane. High-salinity porewater was diluted using deionized water before chemical analysis. Samples for cation analysis were acidified with $6 \mathrm{NHNO}_{3}$ to $\mathrm{pH}<2$. Samples for chemical determinations were analyzed at the School of Environmental Studies of the China University of Geosciences. Major cations and anions were determined using a plasma optical emission spectrum analysis instrument (ICP-OES: ICAP-6300) and an ion chromatograph (ICS-1100), respectively, with an analytical reproducibility lower than $0.01 \mathrm{mg} / \mathrm{L}$. $\mathrm{HCO}_{3}{ }^{-}$was measured using the titration method.

Stable isotope analysis was conducted at the Laboratory of the Geological Survey Institute, China University of Geosciences in Wuhan. Stable isotope values of $\delta^{18} \mathrm{O}$ and $\delta^{2} \mathrm{H}$ were measured using a liquid water isotope analyzer (LGR, IWA-45 EP). In the course of the experiment, three standard solutions (see Table 1) will be used to check the stability of the system for stable isotope measurements. Every standard solution was tested six times, and the mean measured values of the middle 4 times were used to establish standard curve. For stable isotope analysis, porewater samples were rerun six times, and then the average value of the middle 4 times will be obtained based on the standard curve. The replicates were normalized to Vienna Standard Mean Ocean Water (VSMOW) [48] on the basis of (1) and presented in $\delta \%$. The standard deviation of the replicates was less than $0.1 \%$ or $\delta^{18} \mathrm{O}$ and $0.5 \%$ for $\delta^{2} \mathrm{H}$. Based on the standard deviations for replicates and the standard solutions, the analytical precision was calculated to be $0.18 \%$ or for $\delta^{18} \mathrm{O}$ and $0.71 \%$ for $\delta^{2} \mathrm{H}$.

$$
\delta_{\text {sample }}(\% 0)=\left(\frac{R_{\text {sample }}}{R_{\text {standard }}}-1\right) \times 1000 \% \text { o, }
$$

where $\delta_{\text {sample }}$ is the isotope ratio of sample relative to the VSMOW and $R$ is the ${ }^{2} \mathrm{H} /{ }^{1} \mathrm{H}$ or ${ }^{18} \mathrm{O} /{ }^{16} \mathrm{O}$ atomic ratio.

3.3. Seawater Mixing Content. Groundwater in the North Jiangsu coastal plain was often affected by seawater during the transgressions. Determining the proportion of seawater in the groundwater could be used to understand the hydrological geochemical process. The extent of seawater mixing was calculated between two end-member samples by using a mass-balance model [8].

In this study, $\mathrm{Cl}^{-}$is used as the tracer to estimate the seawater mixing proportion. The seawater contribution $\left(f_{\text {sea }}\right)$ is calculated as follows:

$$
f_{\text {sea }}=\frac{C_{\mathrm{Cl} \text {,sample }}-C_{\mathrm{Cl}, f}}{C_{\mathrm{Cl}, \text { sea }}-C_{\mathrm{Cl}, f}},
$$


TABLE 1: The laboratory (LGR) standards and their assigned values.

\begin{tabular}{lcc}
\hline LGR3C & LGR4C & LGR5C \\
\hline$\delta^{2} \mathrm{H}=-97.3 \pm 0.5 \%$ versus & $\delta^{2} \mathrm{H}=-51.6 \pm 0.5 \%$ versus & $\delta^{2} \mathrm{H}=-9.2 \pm 0.5 \%$ versus \\
VSMOW & VSMOW & VSMOW \\
$\delta^{18} \mathrm{O}=-13.39 \pm 0.15 \%$ versus & $\delta^{18} \mathrm{O}=-7.94 \pm 0.15 \%$ versus & $\delta^{18} \mathrm{O}=-2.69 \pm 0.15 \%$ versus \\
VSMOW & VSMOW & VSMOW \\
\hline
\end{tabular}

where $C_{\mathrm{Cl} \text {,sample }}$ is the measured concentration of $\mathrm{Cl}^{-}$in groundwater and $C_{\mathrm{Cl} \text {,sea }}$ and $\mathrm{C}_{\mathrm{Cl}, f}$ are the concentrations of $\mathrm{Cl}^{-}$in the standard seawater and the selected freshwater, respectively.

The seawater contribution $f_{\text {sea }}$ is used to calculate the theoretical concentration of component $j$ :

$$
C_{j, \text { mix }}=f_{\text {sea }} * C_{j, \text { sea }}+\left(1-f_{\text {sea }}\right) * C_{j, f} .
$$

The ionic delta $\left(\Delta C_{j}\right)$ reflects a comparison between the measured concentration and its theoretical concentration $\left(C_{j, \text { mix }}\right)$ :

$$
\Delta C_{j}=C_{j, \text { sample }}-C_{j, \operatorname{mix}} \cdot
$$

\section{Results}

4.1. Salinity Distribution of Water Samples. The chemical compositions of the porewater samples are displayed in Figure 5. The TDS of the porewater in the aquitards is lower than current seawater $(35.0 \mathrm{~g} / \mathrm{L})$, ranging from 0.03 to $26.1 \mathrm{~g} / \mathrm{L}$. On the basis of the various tested TDS concentrations, porewater in the aquitards is divided into three water types: fresh (TDS of $<1 \mathrm{~g} / \mathrm{L}$ ), brackish (TDS of $1-3 \mathrm{~g} / \mathrm{L}$ ), and saline (TDS of 3-30 g/L) water. Fresh porewater is completely absent from the SY3 profile, but presents in cores SY1 and SY2. Three water-bearing subsystems termed the "shallow, middle, and deep systems" had been defined in this study area [29]. Accordingly, porewater samples were classified into three groups.

(1) Group 1 corresponds to porewater samples that were collected from clay-rich sediments in the shallow water system with depths of 2.1-62.6 m (SY1), 10.6-83.8 m (SY2), and $6.4-80.0 \mathrm{~m}$ (SY3). These porewater samples were highly saline, and their TDS concentrations ranged from $0.85 \mathrm{~g} / \mathrm{L}$ to a maximum of $26.1 \mathrm{~g} / \mathrm{L}$.

(2) Group 2 corresponds to porewater samples from clayrich sediments in the middle water system at depths of 62.6-180.0 $\mathrm{m}$ (SY1) and 83.8-120.0 $\mathrm{m}$ (SY2). Most of these porewater samples indicated the chemical signature of the group with TDS values below $1.0 \mathrm{~g} / \mathrm{L}$.

(3) The samples of Group 3 were classified as mixtures of brackish and saline porewater samples taken from deep water system, at depths of 180-250 m (SY1) and 80-253.6 m (SY3). The TDS concentrations were $1.2-7.0 \mathrm{~g} / \mathrm{L}$, and some small variations of ion concentrations with depths were evident in each core.

4.2. Ion Trends. $\mathrm{Cl}^{-}, \mathrm{Na}^{+}, \mathrm{Ca}^{2+} \mathrm{Mg}^{2+}, \mathrm{SO}_{4}{ }^{2-}$, and $\mathrm{Br}^{-}$ concentrations in the porewater chemical compositions along the depth were presented in Figure 5. The dominant anion in most porewater samples was $\mathrm{Cl}^{-}$(up to $98 \%$ of the total anion concentration), followed by $\mathrm{SO}_{4}{ }^{2-}$, especially in saline and brackish porewater samples. The dominant cation in most porewater samples was $\mathrm{Na}^{+}$(up to $96 \%$ of the total anion concentration), followed by $\mathrm{Ca}^{2+}$ and $\mathrm{Mg}^{2+}$. In Group 1 , their concentrations surged at a depth of approximately $20-50 \mathrm{~m}$ and then decreased rapidly. The maximum $\mathrm{Cl}^{-}$ value reached $455.2 \mathrm{meq} / \mathrm{L}$, which is higher than that of the near-shore seawater values (420-448.7 meq/L). In Group 2 , the porewater samples with the lowest salinity had the characteristics of freshwater. Group 3 had brackish and saline porewater characteristics, and the total ion concentrations are higher than Group 2 samples.

Both $\mathrm{Cl}^{-}$and $\mathrm{Br}^{-}$concentrations are valuable indices for investigating the origin and evolution of groundwater [49]. In this study, Group 2 samples had relatively low $\mathrm{Br}^{-}$values, whereas Group 1 had higher values, some $(0.83-1.10 \mathrm{meq} / \mathrm{L})$ of which even exceeded the $\mathrm{Br}^{-}$concentrations of standard seawater (0.81 meq/L [50]) (Figure 5). The Group 1 samples had a wide range of $\mathrm{Cl} / \mathrm{Br}$ molar ratios ranging from 181.6 to 904.8. Except for some samples from the SY1 core, most of the $\mathrm{Cl} / \mathrm{Br}$ molar ratios were close to or slightly below the nearshore seawater values, as depicted in Figure 6(c). The molar $\mathrm{Cl} / \mathrm{Br}$ ratios in most Group 3 samples were relatively variable and lower than the standard seawater value and ranged from 308.9 to 726.5 .

As illustrated in Figure 6(a), Group 1 and Group 3 saline porewaters were characterized by low $\mathrm{Na} / \mathrm{Cl}$ ratios compared with Group 2 samples. For brackish porewater samples in Group 3, Na/Cl ratios were higher than normal seawater. By contrast, Group 2 samples presented a wide range and exceeded the seawater and rainwater value. The $\mathrm{Ca} / \mathrm{Cl}$ ratios in most Group 1 and 3 porewater samples were higher than seawater. For Group 2 samples, $\mathrm{Ca} / \mathrm{Cl}$ ratios were below that of the rainwater (Figure 6(b)).

4.3. Stable Isotope Compositions $\left(\delta^{18} \mathrm{O}\right.$ and $\left.\delta^{2} H\right)$. The $\delta^{18} \mathrm{O}$ and $\delta^{2} \mathrm{H}$ values in Group 1 varied between $-8.5 \%$ and $-2.1 \%$, and $\delta^{2} \mathrm{H}$ values were between $-54.6 \%$ and $-17.3 \%$. The observed stable isotope values generally decreased with depth (Figure 5). Group 2 samples had narrow ranges, between $-8.5 \%$ and $-7.6 \%$ for $\delta^{18} \mathrm{O}$ and between $-54.6 \%$ and $-53.2 \%$ for $\delta^{2} \mathrm{H}$. The $\delta^{18} \mathrm{O}$ and $\delta^{2} \mathrm{H}$ values in Group 3 samples ranged from $-7.1 \%$ o to $-9.4 \%$ ond from $-56.8 \%$ o to $-66.9 \%$, respectively.

A local meteoric water line (LMWL, $\delta^{2} \mathrm{H}=5.8 \delta^{18} \mathrm{O}-$ 6.79, $n=44$, and $R^{2}=0.87$, Figure 7) was estimated on the basis of the average monthly rainfall monitored from January 


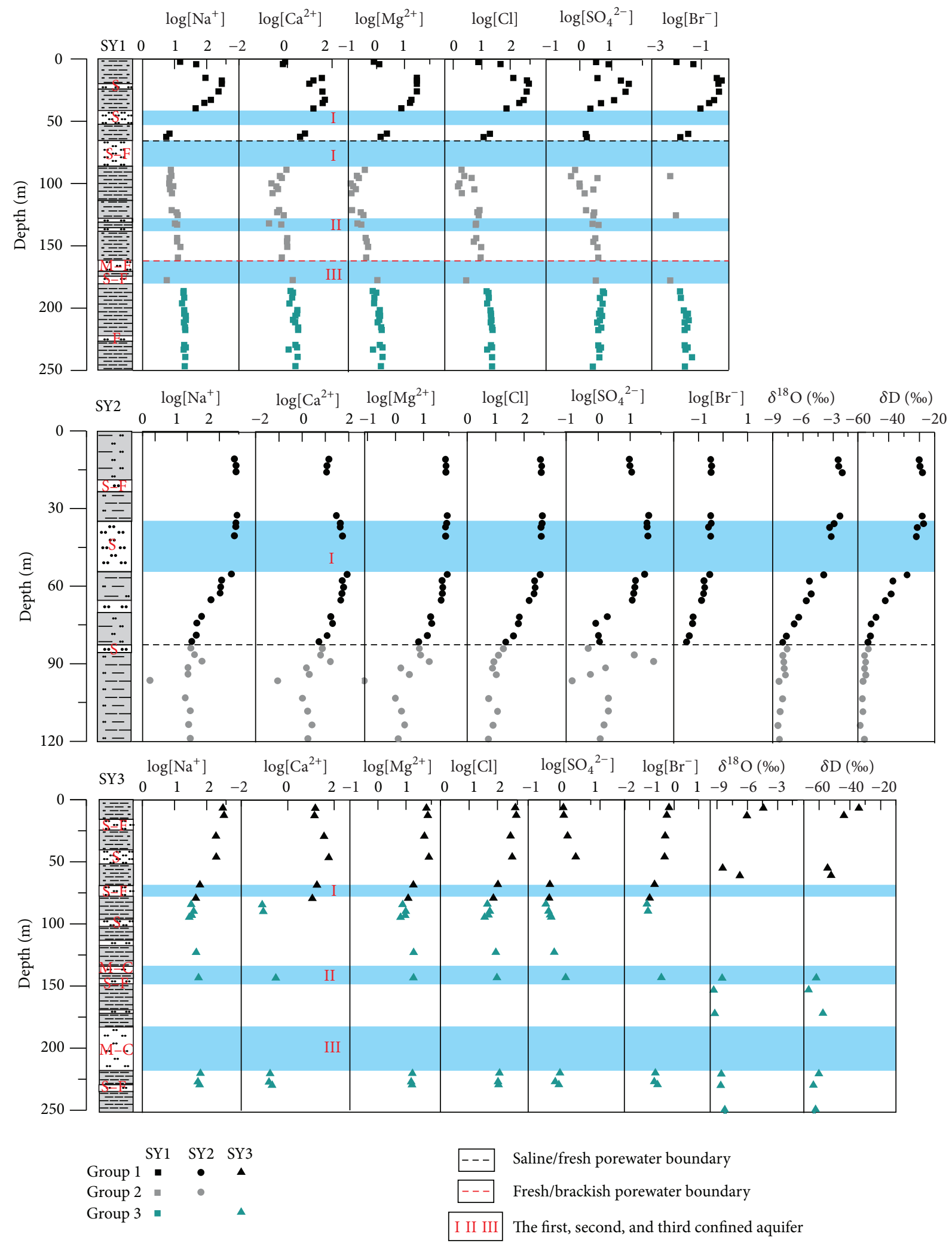

Figure 5: Solute concentrations and stable isotopes $\left(\delta^{18} \mathrm{O}, \delta^{2} \mathrm{H}\right)$ of porewater versus depth. 

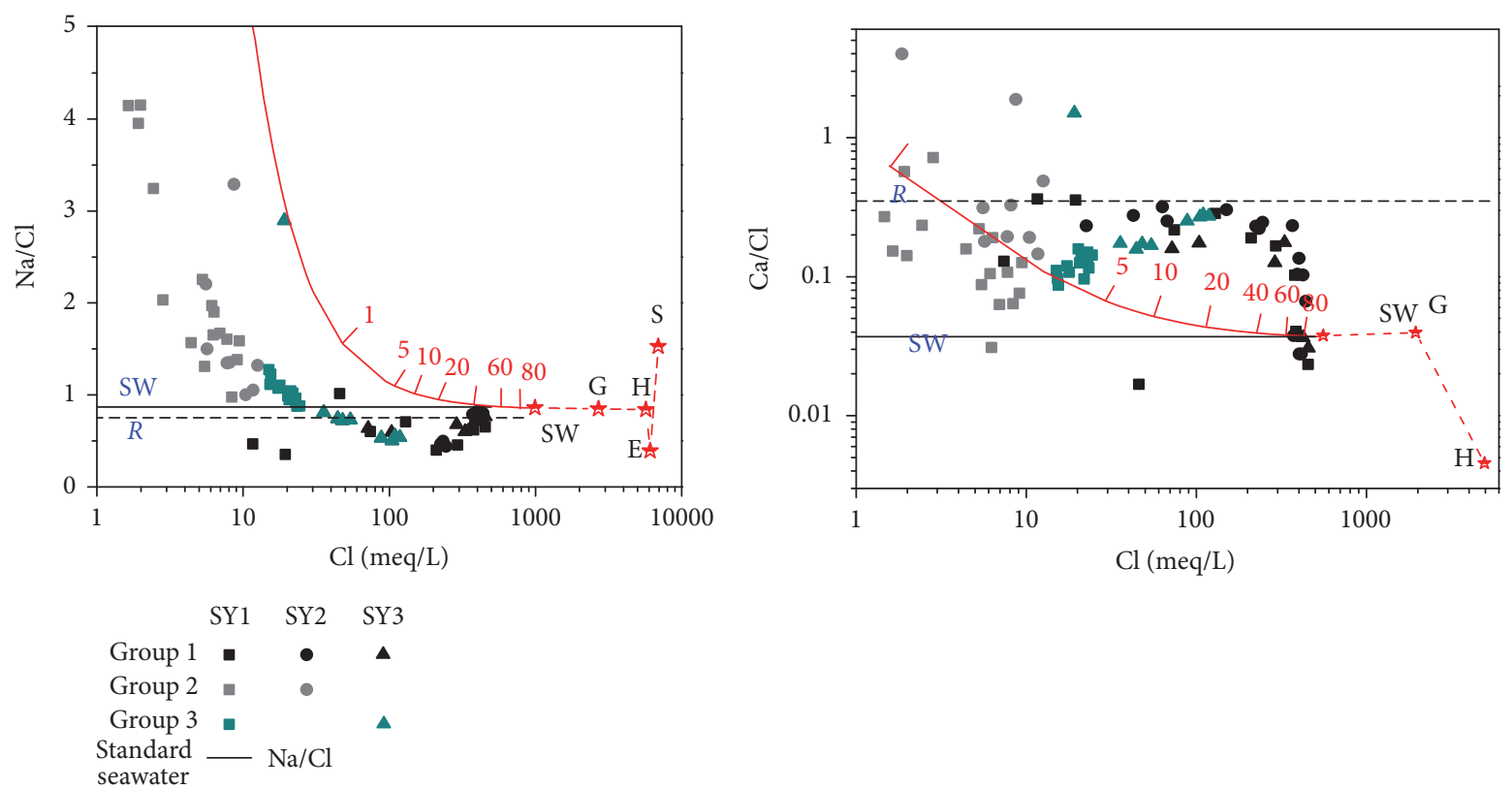

(a)
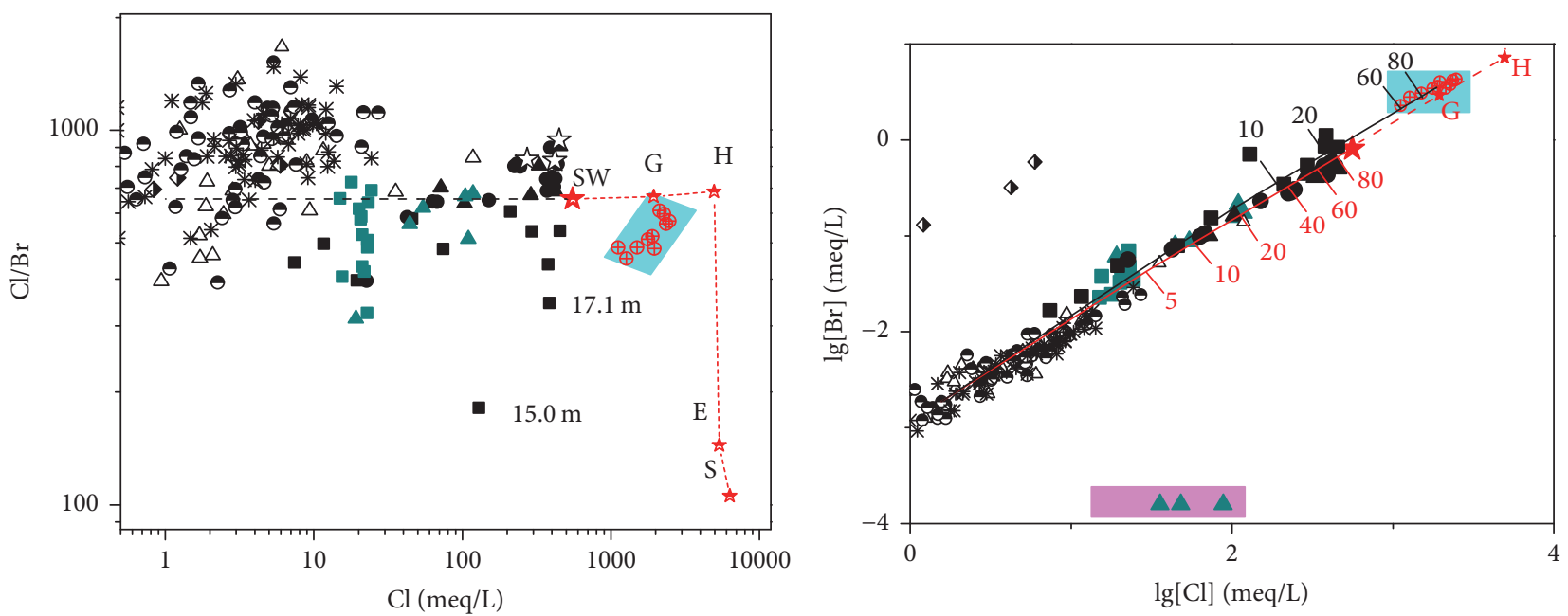

is Near-shore seawater

$\star$ Standard seawater

$\oplus$ Brine
$\triangle$ Phreatic water
$\checkmark 1$ st confined aquifer
- 2nd confined aquifer
* 3rd confined aquifer

(c)

(d)

FIGURE 6: Evolution of hydrochemical ratios with increasing salinity of porewaters. The near-shore seawater samples were given by Fu [22]. Brine samples were collected from Han et al. [10]. $R$ indicates ratios in rainwater, based on data from Zhang et al. [51]. The seawater dilution line between standard seawater and fresh aquifer groundwater is illustrated in red line, and the numbers along with the mixed line stand for the percentage (\%) of seawater mixing. The seawater evaporation trajectory (red dashed line) was given by Fontes and Matray [52]; SW, G, H, $\mathrm{E}$, and $\mathrm{S}$ represent points of standard seawater, precipitation of gypsum, halite, epsomite, and sylvite, respectively.

to September between 1986 and 1990 at Yantai station, which is the nearest coastal station with similar climatic conditions [53]. The stable isotope compositions of aquifer groundwater and surface water were taken from $\mathrm{Fu}[22]$ and $\mathrm{Ha}$ et al. [28] (Figure 7) to identify the sources of porewaters. In the plot of $\delta^{2} \mathrm{H}$ against $\delta^{18} \mathrm{O}$, three groups of points, surface water, and groundwater in the aquifers were close to the LMWL. The $\delta^{18} \mathrm{O}$ and $\delta^{2} \mathrm{H}$ values in the Group 3 samples and the deep confined groundwater of the Huai River basin were characterized by more depleted $\delta$-values compared with Group 1 and Group 2 porewater.

\section{Discussion}

5.1. Origin of Porewater. Group 1 samples had $\delta^{18} \mathrm{O}$ and $\delta^{2} \mathrm{H}$ values between $-8.5 \%$ and $-2.1 \%$ and between $-54.6 \%$ o 


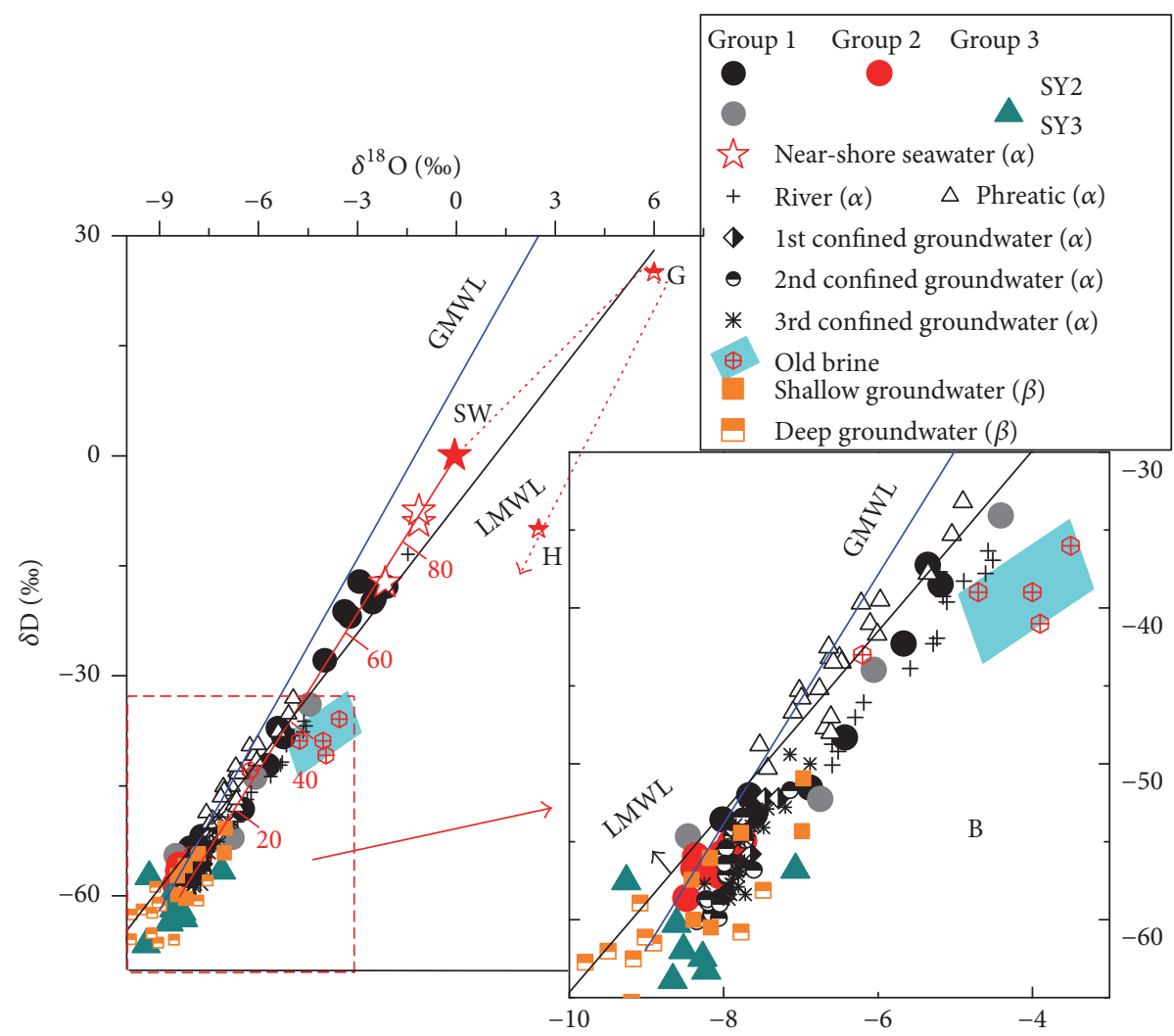

FIGURE 7: Plots of $\delta^{2} \mathrm{H}$ versus $\delta^{18} \mathrm{O}$ for porewater, aquifer groundwater, and river water samples. Samples with $(\alpha)$ represent the water samples in the study area which were collected from $\mathrm{Fu}$ [22] based on aqueous analyses. Samples with $(\beta)$ represent aquifer groundwater samples in the Huai River basin that were obtained from Ha et al. [28]. The LMWL $\left(\delta^{2} \mathrm{H}=5.8 \delta^{18} \mathrm{O}-6.79\right)$ was plotted based on the $\delta^{18} \mathrm{O}$ and $\delta^{2} \mathrm{H}$ values of the average monthly rainfall at the nearest coastal station. The mixing line between the standard seawater and fresh aquifer groundwater $\left(\delta^{2} \mathrm{H}:-60.1 \%\right.$; $\delta^{18} \mathrm{O}:-8.4 \%$ ) is depicted in red.

and $-17.3 \%$, which were more enriched than those of the groundwater in the first confined aquifer beneath the aquitard, as depicted in Figure 7. The $\delta^{18} \mathrm{O}$ and $\delta^{2} \mathrm{H}$ values of Group 1 samples were mostly scattered around the LMWL, suggesting that atmospheric precipitation was their predominant origin. The maximal $\delta^{18} \mathrm{O}$ and $\delta^{2} \mathrm{H}$ values in Group 1 were $-2.1 \%$ and $-18.0 \%$ consistent with the values of nearshore seawater. Based on the mass-balance mixing model (see (2)), the seawater mixing proportions were estimated to be between $2 \%$ and $82 \%$ in Group 1 . In addition, the plots of $\delta^{18} \mathrm{O}$ and $\delta^{2} \mathrm{H}$ fell along the mixing line between standard seawater and fresh aquifer groundwater. This indicates that the Group 1 porewater originated chiefly from seawater and was subsequently diluted by the infiltration of meteoric water during a regression period. The major ion concentrations and $\delta^{18} \mathrm{O}$ and $\delta^{2} \mathrm{H}$ values tended to decrease with depth between $20 \mathrm{~m}$ and $80 \mathrm{~m}$, proving that the sooner the saline pore water develops, the stronger the dilution effect is [54]. Furthermore, no obvious discontinuous vertical distribution occurred in the stable isotopic profiles. Presumably, the Group 1 samples were derived from seawater formed in the Holocene period around $10 \mathrm{ka} \mathrm{BP}-1,128 \mathrm{AD}$, because seawater from the Holocene period had generally retreated from the study area by 1,128 AD (Figure 1(b)) [55].
By contrast, Group 2 samples with depleted stable isotope values deviated from the mixing trend line, indicating no evidence for the involvement of seawater. On the other hand, these samples had $\mathrm{Br}^{-}$concentrations below detection, further corroborating freshwater recharge for Group 2. Their $\delta^{18} \mathrm{O}$ values ranging from $-8.5 \%$ o to $-7.6 \%$ were close to the LMWL, suggesting Group 2 porewater was mainly derived from atmospheric water. Some overlaps in Group 2 porewater and the second confined groundwater samples were observed (Figure 7), indicating that the vertical diffusive mixing between the porewater and aquifer groundwater possibly existed. Based on an analysis of carbon isotopic data $\left({ }^{14} \mathrm{C}\right)$, groundwater ages in the second and third aquifers turned out to be around $30 \mathrm{kaBP}[22,30]$. Thus, recharge under cold climate conditions in the Late Pleistocene (e.g., during the glacial period) is supported by the depleted and identical stable isotopic signatures.

The $\delta^{18} \mathrm{O}$ and $\delta^{2} \mathrm{H}$ values of Group 3 samples and deep aquifer groundwater of the Huai River basin were similar; however, the TDS concentrations for most of the deep aquifer groundwater in the Huai River basin were less than $1.0 \mathrm{~g} / \mathrm{L}$ [28]. Two transgressions (MIS 5, about 110-70 ka BP; MIS 1, around $10 \mathrm{ka} \mathrm{BP}$ ) had been reported and accepted as having occurred in this study area $[56,57]$. Given that the estimated 
age of groundwater in the overlying third confined aquifer was around $30 \mathrm{ka} \mathrm{BP}[22,30]$, Group 3 samples with high salinity (TDS: $1.2-7.0 \mathrm{~g} / \mathrm{L}$ ) were mainly attributed to seawater origin in transgression with an age of 70-110 ka BP during the Late Pleistocene. As shown in Figure 6(d), the proportion of seawater mixing in porewater was less than $20 \%$, and most of the samples contained less than $5 \%$. The fact that these samples were diluted by palaeofreshwater with depleted stable isotopes similar to those of the deep aquifer groundwater in the Huai River basin is supported by the fact that a small contribution of seawater has a great and measureable influence on water chemistry but a limited effect on $\delta^{18} \mathrm{O}$ and $\delta^{2} \mathrm{H}$ values [58].

5.2. Salinization of Porewater. Old brine has been identified in Laizhou Bay, approximately $200 \mathrm{~km}$ north of the study area $[8,59]$ (Figure 1(a)). Old brine was confirmed to originate from ancient seawater, and evapotranspiration was the dominant mechanism of brine formation [10]. Based on the ${ }^{14} \mathrm{C}$ data, the old brine was deduced to form in the Holocene over a period of approximately $2.3-7.0 \mathrm{ka} \mathrm{BP}$. Around the same time, some palaeolagoons formed in the Jiangsu coastal plain $[60,61]$. After the sea level dropped, the high lagoon surface and abundant surface water (e.g., many branches of the Huai River and palaeo-yellow river) resulted in the brine being flushed out [60]. In addition, based on the archaeological evidence, a large number of marine salterns were present along the paleocoastline between 1,300 and 1,900 AD [62]. Old brine likely existed in the study area and later was eventually displaced, just like Qingdao (another area in the coastal plain) [63].

A well-correlated relationship between $\mathrm{Cl}^{-}$and $\mathrm{Br}^{-}$was observed, and most $\mathrm{Cl} / \mathrm{Br}$ molar ratios in Group 1 samples were scattered around the dilution line of standard seawater (Figures 6(c) and 6(d)). It is deemed that the salinity and $\mathrm{Br}^{-}$of Group 1 samples were mainly derived from seawater. Some samples had $\mathrm{Cl} / \mathrm{Br}$ molar ratios less than the normal seawater. The SY1 core samples were likely influenced by the old brine, leading to the low $\mathrm{Cl} / \mathrm{Br}$ ratios with respect to normal seawater. Considering that Group 1 samples were mainly collected from marine sediments, the release of $\mathrm{Br}^{-}$ from diagenesis of marine organic material, the adsorption of $\mathrm{Br}^{-}$on clay minerals, and selective concentration of $\mathrm{Br}^{-}$ through the clay membrane effects may also be responsible for the observed low $\mathrm{Cl} / \mathrm{Br}$ ratios $[50,64]$. Furthermore, two samples at depths of 15.0 and $17.1 \mathrm{~m}$ had notably rich $\mathrm{Br}^{-}$ concentrations, consistent with the elevated $\mathrm{NO}_{3}{ }^{-}$concentration (up to $0.99 \mathrm{meq} / \mathrm{L}$ ), which seems to probably be also attributed to artificial factor (such as pesticides) [44].

The $\mathrm{Cl} / \mathrm{Br}$ ratios in most of Group 3 samples were low with respect to normal seawater, as illustrated in Figure 6(c). In the diagram of $\mathrm{Br}^{-}$and $\mathrm{Cl}^{-}$, most of the samples tended to scatter around the mixing lines. A linear relationship between $\mathrm{Br}^{-}$ and $\mathrm{Cl}^{-}$was observed, with some $\mathrm{Br}^{-}$enriched relative to the expected path for standard seawater and freshwater. Groundwater in the adjacent aquifers and deep aquifer groundwater in the Huai River basin were proved to mainly contain brackish water or freshwater from the Late Pleistocene [22, $28,30]$. In addition, the upper thick low-permeability clay layers may have the ability to impede the leakage of brine formed in the Holocene. For the porewater in the deep aquitards, a contribution of brine to porewater composition seems less likely in comparison with the groundwater in the adjacent aquifers. The salinity possibly was derived from the relict palaeoseawater. The low $\mathrm{Cl} / \mathrm{Br}$ ratios relative to seawater might be related to diagenesis of marine organic matter with $\mathrm{Br}^{-}$release, the adsorption of $\mathrm{Br}^{-}$on clay minerals, and selective concentration of $\mathrm{Br}^{-}$through the clay membrane effects $[50,64]$.

5.3. Water-Rock Interaction. $\mathrm{Cl}^{-}$was deemed to behave relatively conservatively and to be a useful tracer to distinguish the origins of salinity [65]. To highlight the different diagenetic reactions contributing to porewater compositions, some plots of relations among major elements and ion $/ \mathrm{Cl}$ molar ratios are displayed in Figure 6.

As indicated in Figure 6, Na/Cl ratios in the Group 1 and Group 3 porewater samples ranging wildly from 0.31 to 2.90 relative to seawater (0.86) indicated the occurrence of both $\mathrm{Na}^{+}$enrichment and depletion processes. The $\mathrm{Ca} / \mathrm{Cl}$ ratios were mostly higher than seawater. To identify the processes that modified the original contents of the Group 1 and Group 3 samples, the ionic deltas of $\mathrm{Na}^{+}$and $\mathrm{Ca}^{2+}$ were calculated based on (2), (3), and (4).

As illustrated in Figure 8(a), the values of $\Delta$ Ca had inverse linear correlations with $\Delta \mathrm{Na}$ in the Group 1 porewater, with slopes of $-0.41\left(R^{2}=0.60\right)$ and $-0.66\left(R^{2}=0.97\right)$ for the Group 3 porewater. These results indicate that cation exchange plays a crucial role in $\mathrm{Na}^{+}$depletion. $\mathrm{Na}^{+}$adsorbed on the clay surface and albitization may also be responsible for the high $\mathrm{Na}^{+}$deficiency [66].

In contrast to the Group 1 and Group 3 samples, the Group 2 samples had high $\mathrm{Na} / \mathrm{Cl}$ molar ratios ranging from 1.00 to 6.93 , whereas lower $\mathrm{Ca} / \mathrm{Cl}$ ratios relative to rainfall were observed (Figures 6(a) and 6(b)). To examine the cation exchange process of porewater, the plot of $\left(\mathrm{Ca}^{2+}+\mathrm{Mg}^{2+}\right.$ $\left.\mathrm{HCO}_{3}{ }^{-}-\mathrm{SO}_{4}{ }^{2-}\right)$ versus $\left(\mathrm{Na}^{+}+\mathrm{K}^{+}-\mathrm{Cl}^{-}\right)$was used [67]. As illustrated in Figure 8(b), most of the samples were plotted around the $-1: 1$ line, implying that cation exchange was mainly responsible for the elevated $\mathrm{Na}^{+}$. The portion of the samples plot below the $-1: 1$ line implies that the minor excess $\left(\mathrm{Na}^{+}+\mathrm{K}^{+}\right)$was contributed by hydrolysis of silicate minerals (e.g., $2 \mathrm{NaAlSi}_{3} \mathrm{O}_{8 \text { (Albite) }}+2 \mathrm{CO}_{2}+11 \mathrm{H}_{2} \mathrm{O} \rightarrow 2 \mathrm{Na}^{+}+$ $\left.\mathrm{Al}_{2} \mathrm{Si}_{2} \mathrm{O}_{5}(\mathrm{OH})_{4(\text { Kaolinite })}+4 \mathrm{H}_{4} \mathrm{SiO}_{4}+2 \mathrm{HCO}_{3}{ }^{-}\right)$because the aquitards of the study area contain abundant silicate weathering products such as kaolinite, illite montmorillonite, and mica minerals $[8,34]$ and the release of $\mathrm{Na}^{+}$from exchange sites of clay minerals [10]. Some other points are above the $-1: 1$ line, indicating that the additional $\left(\mathrm{Ca}^{2+}+\mathrm{Mg}^{2+}\right.$ $\mathrm{HCO}_{3}{ }^{-}-\mathrm{SO}_{4}{ }^{2-}$ ) inputs may have been derived from the weathering of Ca-bearing plagioclase and calcite, while yet again cation exchange was most noticeable for $\mathrm{Na}^{+}$enrichment and $\mathrm{Ca}^{2+}$ depletion in the Group 2 porewater.

\section{Conclusions}

This study provides insights into the origin and evolution of the porewater in aquitards using hydrochemical and 


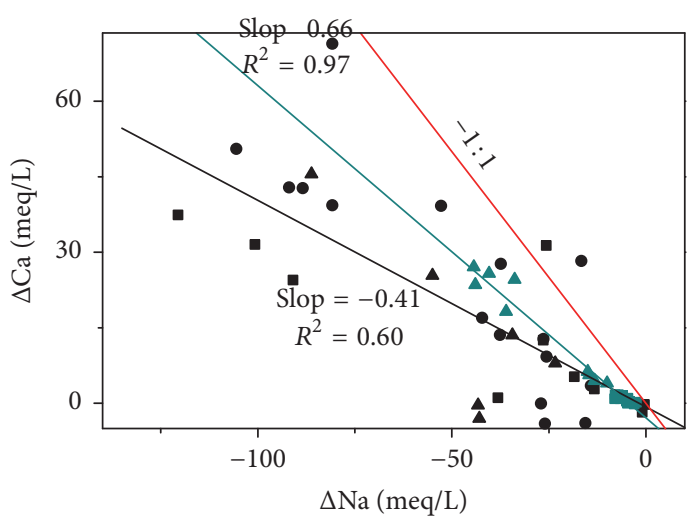

(a)

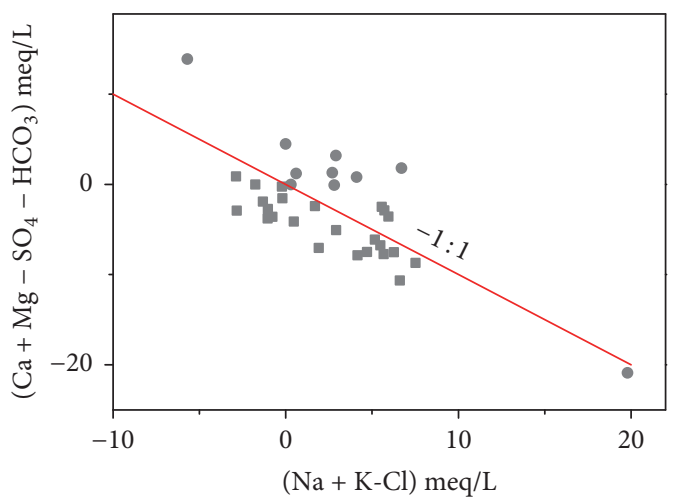

(b)

Figure 8: (a) $\Delta$ Ca versus $\Delta \mathrm{Na}$; (b) $\left(\mathrm{Ca}^{2+}+\mathrm{Mg}^{2+}-\mathrm{HCO}_{3}{ }^{-}-\mathrm{SO}_{4}{ }^{2-}\right)$ versus $\left(\mathrm{Na}^{+}+\mathrm{K}^{+}-\mathrm{Cl}^{-}\right)$of aquitard porewater. Symbols are the same as Figure 6 .

stable isotopic evidence based on samples from three deep boreholes drilled into the North Jiangsu coastal plain, China. Three groups were classified by the water-bearing subsystems of "shallow, middle, and deep system" in this study area.

Regarding porewater samples, the $\delta^{2} \mathrm{H}$ and $\delta^{18} \mathrm{O}$ values were plotted around the LMWL, indicative of signatures of atmospheric precipitation. Chemical data indicated significant variations in salinity and hydrochemical constituents of porewaters, which were interpreted in terms of different origins. The trapped seawater during Holocene transgressions was the major source producing salinity of the Group 1 samples. The Group 2 samples had freshwater characteristics and resulted from atmospheric precipitation in a cold climate. According to the analysis of the plots of $\mathrm{Br}^{-}$versus $\mathrm{Cl}^{-}$and $\delta^{2} \mathrm{H}$ versus $\delta^{18} \mathrm{O}$, it is deduced that the Group 3 samples evolved from the remaining palaeoseawater from the Late Pleistocene and were subsequently diluted by palaeofreshwater.

Water-rock interaction also accounted for the differences between the initial and current porewater solutions as a result of the long residence times of the water samples. $\mathrm{Na}^{+}$adsorbed on clay surfaces and albitization were likely associated with the Group 1 and Group 3 constituents, as well as cation exchange between $\mathrm{Ca}^{2+}$ and $\mathrm{Na}^{+}$. By contrast, cation exchange was more noticeable for the Group 2 samples with low salinity. The dissolved $\mathrm{Ca}^{2+}$ is exchanged mainly for $\mathrm{Na}^{+}$, and weathering of silicate minerals and Ca-bearing plagioclase may provide only a minor contribution.

The present study attempted to ascertain the distributions of porewaters, the origins of salt, and the hydrochemical evolution in porewaters with the long residence times. The results have crucial implications for assessing the salinization of porewater in coastal aquitards. The observations of this study could serve as a reference for porewater quality in the coastal aquitards and verify that thick aquitards have a function for preserving ancient water.

\section{Conflicts of Interest}

The authors declare that they have no conflicts of interest.

\section{Acknowledgments}

Financial support was provided by the National Natural Science Foundation of China (Grant nos. 41502231 and 41272258). The authors thank Yalei Liu and Yunquan Wang for their useful comments and advice, as well as all members of the Geological Survey of Jiangsu Province, China, for their assistance and support in the process of sampling and data collection.

\section{References}

[1] V.E. A. Post, "Fresh and saline groundwater interaction in coastal aquifers: is our technology ready for the problems ahead?" Hydrogeology Journal, vol. 13, no. 1, pp. 120-123, 2005.

[2] M. Q. Shi, Spatial distribution of population in the low elevation coastal zone and assessment on vulnerability of natural disaster in the coastal area of China, Master thesis of Shanghai Normal University, 2012.

[3] L. Shi and J. J. Jiao, "Seawater intrusion and coastal aquifer management in China: a review," Environmental Earth Sciences, vol. 72, no. 8, pp. 2811-2819, 2014.

[4] X. Shi, F. Jiang, Z. Feng, B. Yao, H. Xu, and J. Wu, "Characterization of the regional groundwater quality evolution in the North Plain of Jiangsu Province, China," Environmental Earth Sciences, vol. 74, no. 7, pp. 5587-5604, 2015.

[5] P. Pulido-Leboeuf, "Seawater intrusion and associated processes in a small coastal complex aquifer (Castell de Ferro, Spain)," Applied Geochemistry, vol. 19, no. 10, pp. 1517-1527, 2004.

[6] M. A. Schiavo, S. Hauser, and P. P. Povinec, "Stable isotopes of water as a tool to study groundwater-seawater interactions in coastal south-eastern Sicily," Journal of Hydrology, vol. 364, no. 1-2, pp. 40-49, 2009.

[7] F. Larsen, L. V. Tran, H. Van Hoang, L. T. Tran, A. V. Christiansen, and N. Q. Pham, "Groundwater salinity influenced by Holocene seawater trapped in incised valleys in the Red River delta plain," Nature Geoscience, vol. 10, no. 5, pp. 376-381, 2017.

[8] D. M. Han, X. F. Song, M. J. Currell, J. L. Yang, and G. Q. Xiao, "Chemical and isotopic constraints on evolution of groundwater salinization in the coastal plain aquifer of Laizhou Bay, China," Journal of Hydrology, vol. 508, pp. 12-27, 2014. 
[9] L. Aquilina, B. Ladouche, N. Doerfliger et al., "Origin, evolution and residence time of saline thermal fluids (Balaruc springs, southern France): Implications for fluid transfer across the continental shelf," Chemical Geology, vol. 192, no. 1-2, pp. 1-21, 2002.

[10] D. Han, V. E. A. Post, and X. Song, "Groundwater salinization processes and reversibility of seawater intrusion in coastal carbonate aquifers," Journal of Hydrology, vol. 531, pp. 10671080, 2015.

[11] G. Mongelli, S. Monni, G. Oggiano, M. Paternoster, and R. Sinisi, "Tracing groundwater salinization processes in coastal aquifers: a hydrogeochemical and isotopic approach in the NaCl brackish waters of northwestern Sardinia, Italy," Hydrology and Earth System Sciences, vol. 17, no. 7, pp. 2917-2928, 2013.

[12] G. Cao, C. Zheng, B. R. Scanlon, J. Liu, and W. Li, "Use of flow modeling to assess sustainability of groundwater resources in the North China Plain," Water Resources Research, vol. 49, no. 1, pp. 159-175, 2013.

[13] M. J. Hendry and L. I. Wassenaar, "Controls on the distribution of major ions in pore waters of a thick surficial aquitard," Water Resources Research, vol. 36, no. 2, pp. 503-514, 2000.

[14] D. C. Thorstenson, D. W. Fisher, and M. G. Croft, "The geochemistry of the fox hills-basal hell creek aquifer in southwestern North Dakota and northwestern South Dakota," Water Resources Research, vol. 15, no. 6, pp. 1479-1498, 1979.

[15] M. Khaska, C. Le Gal La Salle, J. Lancelot et al., "Origin of groundwater salinity (current seawater vs. saline deep water) in a coastal karst aquifer based on $\mathrm{Sr}$ and $\mathrm{Cl}$ isotopes. Case study of the La Clape massif (southern France)," Applied Geochemistry, vol. 37, no. 10, pp. 212-227, 2013.

[16] S. Najib, A. Fadili, K. Mehdi, J. Riss, A. Makan, and H. Guessir, "Salinization process and coastal groundwater quality in Chaouia, Morocco," Journal of African Earth Sciences, vol. 115, pp. 17-31, 2016.

[17] M. Cyr and A. Daidié, "Optimization of a high-pressure pore water extraction device," Review of Scientific Instruments, vol. 78, no. 2, article 023906, 2007.

[18] L. I. Wassenaar, I. Leonard, and M. J. Hendry, "Improved piezometer construction and sampling techniques to determine pore water chemistry in aquitards," Groundwater, vol. 37, no. 4, pp. 564-571, 2010.

[19] M. J. Hendry, L. I. Wassenaar, and T. Kotzer, "Chloride and chlorine isotopes $(36 \mathrm{Cl}$ and $\delta 37 \mathrm{Cl})$ as tracers of solute migration in a thick, clay-rich aquitard system," Water Resources Research, vol. 36, no. 1, pp. 285-296, 2000.

[20] W. A. Timms and M. J. Hendry, "Quantifying the impact of cation exchange on long-term solute transport in a clay-rich aquitard," Journal of Hydrology, vol. 332, no. 1-2, pp. 110-122, 2007.

[21] J. Li, X. Liang, M. Jin, G. Xiao, J. He, and Y. Pei, “Geochemistry of clayey aquitard pore water as archive of paleo-environment, western Bohai Bay," Journal of Earth Science, vol. 26, no. 3, pp. 445-452, 2015.

[22] C. C. Fu, The Hydrochemical Characteristics And Processes for Salinity Sources of The Deep Confined Groundwater in The Coastal Plain of Huai River Basin, Jilin University, 2015.

[23] Y. L. Fu, "Evaluation of groundwater resource forecast in Yancheng," Resources Surveyand Environment, vol. 26, pp. 56-59, 2005.

[24] L. Yi, "Reconciling late Quaternary transgressions in the Bohai Sea, China to the global sea level changes, and new linkage of sedimentary records to three astronomical rhythms," $E G U$ General Assembly Conference, 2013.

[25] H. R. Yang and X. Q. Chen, "Quaternary transgressions, eustatic changes and shifting of shoreline in east China," Marine Geology \& Quaternary Geology, vol. 5, pp. 59-80, 1985.

[26] Y. Wang, Z. K. Zhang, D. K. Zhu, J. H. Yang, J. L. Mao, and S. H. Li, "Riversea interaction and the North Jiangsu Plain formation," Quaternary Sciences, vol. 26, Article ID 301320, pp. 301-320, 2006.

[27] C. T. Xue, Y. Q. Zhou, and G. L. Wang, "Reviews of the Yellow river delta super lobes since $700 \mathrm{BC}$," Marine Geolpgy and Quaternary Geology, vol. 23, pp. 23-30, 2003.

[28] C. Y. Ha, J. Q. Zhu, N. J. Ye, J. J. Huang, and J. S. Gong, “The forgotten delta the formation and evolution of Huaihe Delta River," Geological Bulletin of China, vol. 24, pp. 1094-1106, 2005.

[29] H. C. Zhou, "Origin, distribution, and evolution of salt-fresh groundwater in North Jiangsu Basin, China," Environmental Geology and Water Sciences, vol. 12, no. 1, pp. 15-22, 1988.

[30] B. Kang, The study of groundwater evolution and rational exploitation and utilizing in Jiangsu Coastal area, Jilin University, 2017.

[31] G. Y. Zheng, "Quaternary stratigraphic division of the hole QC2 in the southern Huanghai Sea," Marine Geology \& Quaternary Geology, vol. 4, pp. 5-13, 1988.

[32] J. Q. Zhang, J. Liu, X. H. Kong et al., "Clay mineral assemblange of sediments from middle reach of Huaihe River," Marine Geology and Quaternary Geology, vol. 31, pp. 21-29, 2011.

[33] Z. X. Chen, "Clay minerals from drill hole QC1 in South Yellow Sea," Marine Geology and Quaternary Geology, vol. 3, 1990.

[34] Q. Shu, Y. Chen, M. H. Zhang, and Z. J. Zhao, "Environmental significance and clay mineral characteristics of YZ1 core sediments in Zhouzhuang, Northern Jiangsu Plain," Scientia Geographica Sinica, vol. 2, pp. 238-243, 2012.

[35] D. E. Desaulniers, E. Donald, and J. A. Cherry, "Origin and movement of groundwater and major ions in a thick deposit of Champlain Sea clay near Montreal," Canadian Geotechnical Journal, vol. 26, no. 1, pp. 80-89, 1989.

[36] M. J. Hendry and L. I. Wassenaar, "Implications of the distribution of $\sigma \mathrm{D}$ in pore waters for groundwater flow and the timing of geologic events in a thick aquitard system," Water Resources Research, vol. 35, no. 6, pp. 1751-1760, 1999.

[37] M. J. Hendry and G. A. Harrington, "Comparing vertical profiles of natural tracers in the Williston Basin to estimate the onset of deep aquifer activation," Water Resources Research, vol. 50, no. 8, pp. 6496-6506, 2015.

[38] H. N. Waber and J. A. T. Smellie, "Characterisation of pore water in crystalline rocks," Applied Geochemistry, vol. 23, no. 7, pp. 1834-1861, 2008.

[39] M. Mazurek, P. Alt-Epping, A. Bath et al., "Natural tracer profiles across argillaceous formations," Applied Geochemistry, vol. 26, no. 7, pp. 1035-1064, 2011.

[40] P. S. Ridout and R. M. Pagett, "A large volume sediment squeezing system for the analysis of rare earth elements in deep ocean pore waters," Marine Chemistry, vol. 15, no. 3, pp. 193-201, 1984.

[41] R. J. Patterson, S. K. Frape, L. S. Dykes, and R. A. McLeod, "A coring and squeezing technique for the detailed study of subsurface water chemistry," Canadian Journal of Earth Sciences, vol. 15, no. 1, pp. 162-169, 1978.

[42] G. Böttcher, H.-J. Brumsack, H. Heinrichs, and M. Pohlmann, "A new high-pressure squeezing technique for pore fluid extraction from terrestrial soils," Water, Air, \& Soil Pollution, vol. 94, no. 3-4, pp. 289-296, 1997. 
[43] E. Sacchi, J.-L. Michelot, H. Pitsch, P. Lalieux, and J.-F. Aranyossy, "Extraction of water and solutes from argillaceous rocks for geochemical characterisation: methods, processes, and current understanding," Hydrogeology Journal, vol. 9, no. 1, pp. 1733, 2001.

[44] L. Araguás-Araguás, K. Rozanski, R. Gonfiantini, and D. Louvat, "Isotope effects accompanying vacuum extraction of soil water for stable isotope analyses," Journal of Hydrology, vol. 168, no. 1-4, pp. 159-171, 1995.

[45] M. V. Altinier, S. Savoye, J.-L. Michelot et al., "The isotopic composition of pore-water from tournemire argillite (France): An inter-comparison study," Physics and Chemistry of the Earth, vol. 32, no. 1-7, pp. 209-218, 2007.

[46] N. L. Ingraham and C. Shadel, "A comparison of the toluene distillation and vacuum/heat methods for extracting soil water for stable isotopic analysis," Journal of Hydrology, vol. 140, no. 1-4, pp. 371-387, 1992.

[47] Y. Moreau-Le Golvan, J.-L. Michelot, and J.-Y. Boisson, "Stable isotope contents of porewater in a claystone formation (tournemire, France): assessment of the extraction technique and preliminary results," Applied Geochemistry, vol. 12, no. 6, pp. 739-745, 1997.

[48] R. Gonfiantini, "Standards for stable isotope measurements in natural compounds," Nature, vol. 271, no. 5645, pp. 534-536, 1978.

[49] W. M. Edmunds, J. Ma, W. Aeschbach-Hertig, R. Kipfer, and D. P. F. Darbyshire, "Groundwater recharge history and hydrogeochemical evolution in the Minqin Basin, North West China," Applied Geochemistry, vol. 21, no. 12, pp. 2148-2170, 2006.

[50] S. N. Davis, D. O. Whittemore, and F. June, "Uses of chloride/bromide ratios in studies of potable water," Ground Water, vol. 36, no. 2, pp. 338-350, 1998.

[51] Z. F. Zhang, L. J. Shen, B. Zhu, J. Ye, H. L. Wang, and Q. C. Zhang, "Chemical chanracteristics and potential sources of precipitation in Nanjing," Transactions of Atmospheric Sciences, vol. 38, no. 4, pp. 473-482, 2015.

[52] J. C. Fontes and J. M. Matray, "Geochemistry and origin of formation brines from the Paris Basin, France: 1. Brines associated with Triassic salts," Chemical Geology, vol. 109, no. 1-4, pp. 149-175, 1993.

[53] IAEA/WMO, "Global network of isotopes in precipitation the gnip database vienna," http://www-naweb.iaea.org/napc/ih/ IHS_resources_gnip.html, 2006.

[54] J. C. Zhao, J. Liang, and H. S. Cai, "Relation between formation of saltfresh water and waterbearing medium in the plain of North Jiangsu," Journal of Engineering Geology and Hydrogeology, vol. 20, pp. 25-27, 1993.

[55] C. T. Xue, J. Liu, and X. H. Kong, "Preliminary study of holocene Huai river delta on west coastal plain of yellow sea," China Quaternary Research, vol. 30, no. 5, pp. 892-901, 2010.

[56] L. Yi, H.-J. Yu, J. D. Ortiz et al., "Late Quaternary linkage of sedimentary records to three astronomical rhythms and the Asian monsoon, inferred from a coastal borehole in the south Bohai Sea, China," Palaeogeography, Palaeoclimatology, Palaeoecology, vol. 329-330, pp. 101-117, 2012.

[57] S. Ling, "Changes of the palaeogeographic environment in north Jiangsu Plains since the Holocene," Journal of Oceanography of Huanghai Bohaiseas, vol. 8, no. 4, pp. 20-28, 1991.

[58] N. R. Warner, R. B. Jackson, T. H. Darrah et al., "Geochemical evidence for possible natural migration of Marcellus formation brine to shallow aquifers in Pennsylvania," Proceedings of the
National Acadamy of Sciences of the United States of America, vol. 109, no. 30, pp. 11961-11966, 2012.

[59] Y. Xue, J. Wu, S. Ye, and Y. Zhang, "Hydrogeological and hydrogeochemical studies for salt water intrusion on the South Coast of Laizhou Bay, China," Ground Water, vol. 38, no. 1, pp. 38-45, 2000.

[60] S. Ling, "Study on models of the changes about Sheyang lake in historical period," Collections of Essays on Chinese Historical Geography, vol. 3, no. 20, pp. 73-79, 2005.

[61] Z. K. Zhang, L. Xie, Y. F. Zhang, J. Xu, S. H. Li, and Y. Wang, "Sedimentary records of the MIS 3 transgression event in the north Jiangsu plain, China," Quaternary Research, vol. 30, no. 5, pp. 883-891, 2010.

[62] J. L. Bao, Jiangsu coastal salt activity geography and the changes of Human-land relationship in Ming and Qing Dynasties [Ph.D. thesis], Fudan University, Shanghai, China, 2014.

[63] H. You-Song, W. Shao-Qing, and M. Guang-Ian, "The formingstoring environment and abundance conditions of quaternary underground brine in the embayed coast of Qingdao," Chinese Journal of Oceanology and Limnology, vol. 15, no. 4, pp. 332-341, 1997.

[64] F. Bensenouci, J. L. Michelot, J. M. Matray, S. Savoye, M. Massault, and A. Vinsot, "Coupled study of water-stable isotopes and anions in porewater for characterizing aqueous transport through the Mesozoic sedimentary series in the eastern Paris Basin," Marine and Petroleum Geology, vol. 53, pp. 88-101, 2014.

[65] J. Li, X. Liang, Y. Zhang et al., "Salinization of porewater in a multiple aquitard-aquifer system in Jiangsu coastal plain, China," Hydrogeology Journal, vol. 25, no. 8, pp. 2377-2390, 2017.

[66] E. Karro, A. Marandi, and R. Vaikmäe, “The origin of increased salinity in the Cambrian-Vendian aquifer system on the Kopli Peninsula, northern Estonia," Hydrogeology Journal, vol. 12, no. 4, pp. 424-435, 2004.

[67] R. S. Fisher and W. F. Mullican III, "Hydrochemical evolution of sodium-sulfate and sodium-chloride groundwater beneath the Northern Chihuahuan Desert, Trans-Pecos, Texas, USA," Hydrogeology Journal, vol. 5, no. 2, pp. 4-16, 1997. 

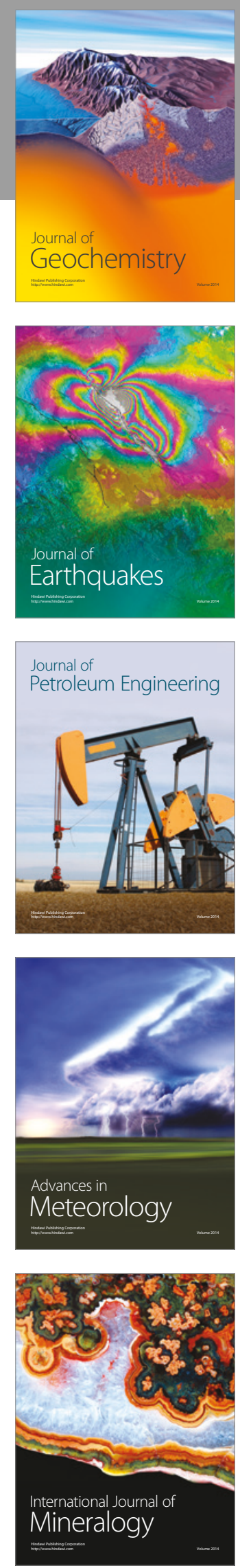
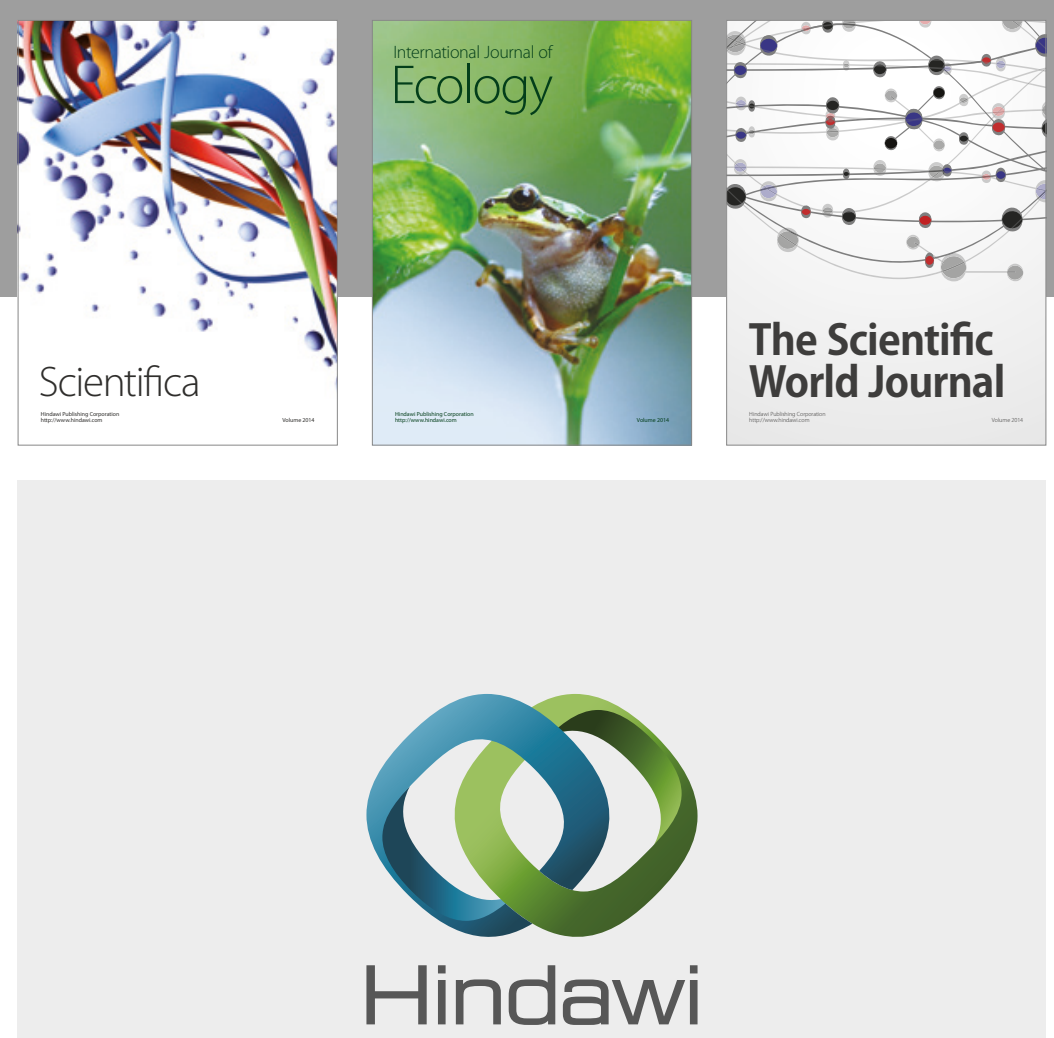

Submit your manuscripts at

https://www.hindawi.com
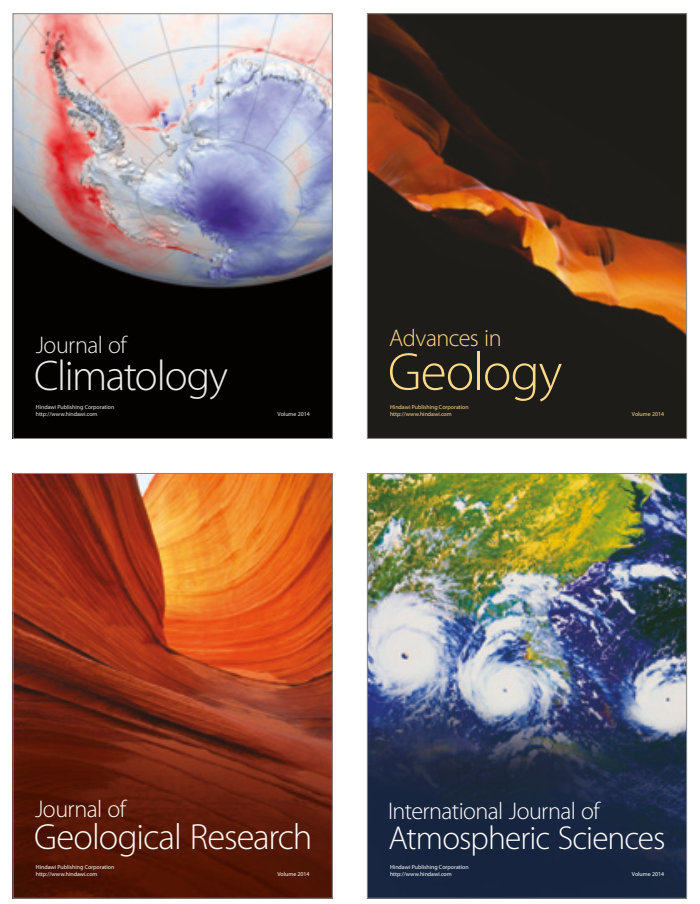

The Scientific

World Journal
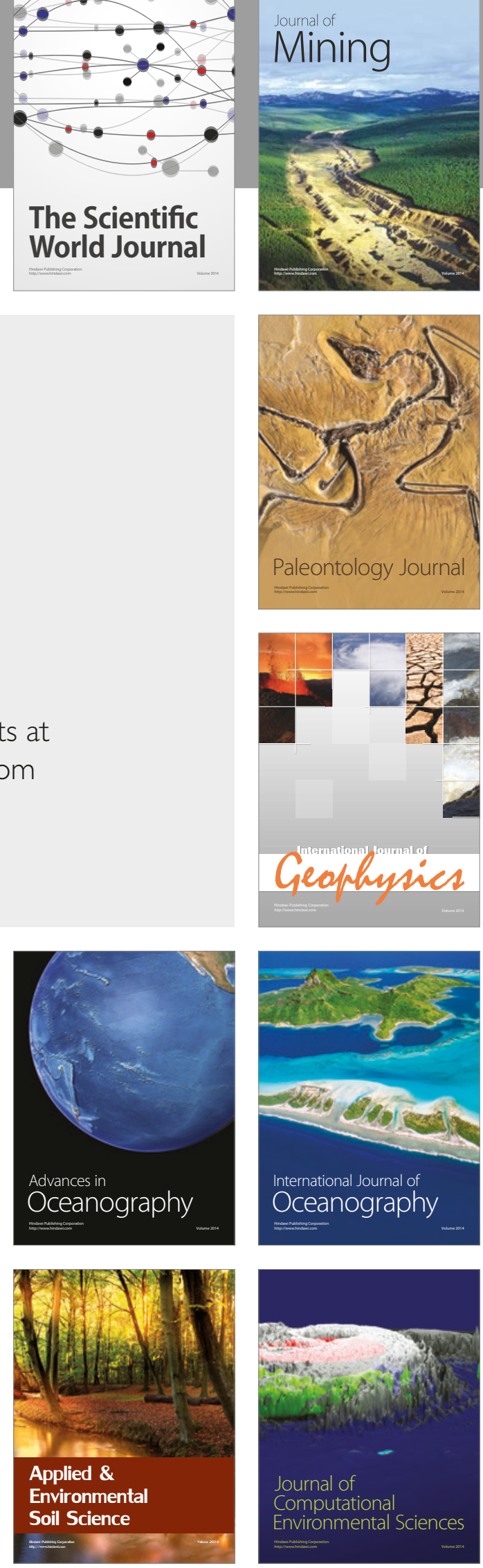